\title{
Unique ability of pandemic influenza to downregulate the genes involved in neuronal disorders
}

\section{Esmaeil Ebrahimie $^{1,2,3 * * * *}$, Zahra Nurollah ${ }^{4 *}$, Mansour Ebrahimi ${ }^{5}$, Farhid Hemmatzadeh ${ }^{6 * *}$, Jagoda Ignjatovic ${ }^{7 * *}$}

${ }^{1}$ Department of Genetics and Evolution, School of Biological Sciences, The University of Adelaide, Adelaide, Australia. Email: esmaeil.ebrahimie@adelaide.edu.au

${ }^{2}$ School of Information Technology and Mathematical Sciences, Division of Information Technology, Engineering and the Environment, University of South Australia, Adelaide, Australia. E-mail: Esmaeil.Ebrahimie@unisa.edu.au

${ }^{3}$ Institute of Biotechnology, Shiraz University, Shiraz, Iran. Email: ebrahimie@shirazu.ac.ir

${ }^{4}$ Department of Biotechnology, Shahrekord University, Shahrekord, Iran. Email: z.nurolah@gmail.com

${ }^{5}$ Department of Biology, School of Basic Sciences, University of Qom, Qom, Iran. Email: mebrahimi14@gmail.com

${ }^{6}$ School of Animal and Veterinary Science, The University of Adelaide, Adelaide, Australia. Email: farhid.hemmatzadeh@adelaide.edu.au

${ }^{7}$ School of Veterinary Science, The University of Melbourne, Melbourne, Australia. Email: jagodai@unimelb.edu.au

** Corresponding authors

*These authors have equal contribution 


\begin{abstract}
Purpose

Pandemic influenza remains as a substantial threat to humans with a widespread panic worldwide. In contrast, seasonal (non-pandemic) has a mild non-lethal infection each year. The underlying mechanisms governing the detrimental effects of pandemic influenza are yet to be known. Transcriptomic-based network discovery and Gene Ontology (GO) analysis of host response to pandemic influenza, compared to seasonal influenza, can shed light on the differential mechanisms which pandemic influenza is employed during evolution.
\end{abstract}

\title{
Methods
}

Here, using microarray data of infected ferrets with pandemic and seasonal influenza (as a model), we evaluated the possible link between altered genes after pandemic infection with activation of neuronal disorders. To this end, we utilized novel computational biology techniques including differential transcriptome analysis, network construction, GO enrichment, and GO network to investigate the underlying mechanisms of pandemic influenza infection and host interaction.

\section{Results}

In comparison to seasonal influenza, pandemic influenza differentially altered the expression of 31 genes with direct involvement in activity of central nervous system. Network topology highlighted the high interactions of IRF1, NKX2-1 and NR5A1 as well as miRNA27A, miRNA19A, and miRNA17. TGFB2, NCOA3 and SP1 were the central transcription factors in networks. Pandemic influenza remarkably downregulated GPM6A and GTPase. GO network demonstrated the key roles of GPM6A and GTPase in regulation of important functions such as synapse assembly and neuron projection.

\section{Discussion}

For the first time, we showed that besides interference with cytokine/chemokine storm and neuraminidase enzyme, H1N1 pandemic influenza is able to directly affect neuronal gene networks. The possibility of application of some key regulators such as GPM6A protein, MIR128, and MIR367 as candidate therapeutic agents is discussed. The presented approach established a new way to unravel unknown pathways in virus-associated central nervous system (CNS) dysfunction by utilizing global transcriptomic data, network and GO analysis. 
Keywords: Central nervous system (CNS) dysfunction; GPM6A; Gene Ontology Enrichment; Gene Ontology network; miRNA128; miRNA367; Pandemic influenza; Transcriptomic analysis; Gene networks

\section{Introduction}

Pandemic influenza, as the most detrimental type of influenza virus, has a proven record of mortality in human history, including Asiatic (Russian) flu in 1889 with 1 million deaths (Valleron et al. 2010), Spanish flu in 1918 with 20-100 million deaths (Mills et al. 2004), Asian flu in 1957 with 1-1.5 million deaths, Hong Kong flu in 1968 with 0.75-1 million deaths, and 2009 pandemic with 18000 deaths (Donaldson et al. 2009).

Susceptible groups to flu infection are children and old people, showing a range of viral infection signs such as fever, cough, petechial rash, respiratory disturbances, pulmonary disease, neurological disorder, and hematological alteration (Calitri et al. 2010). Neural complications, similar to Schizophrenia, Reye's syndrome, Parkinson, and Encephalopathy symptoms, can be seen in influenza infection (Toovey 2008). Also, other neural symptoms such as migraine exacerbation, exacerbation of myasthenia gravis, acute ischaemic stroke and seizure have been reported (Tan et al. 2010). It has been demonstrated that influenza A alters the expression of some genes involved in nervous system function (Mori et al. 2001; Fatemi et al. 2005).

Up to now, the observed effects of influenza on nervous system have been annotated solely to dysfunction in exuberant cytokine/chemokine response and neuraminidase enzyme (Lee et al. 2010; Maurizi 1985), and the possibility of involvement of the other pathways is extensively ignored. However, recently, it has been discussed that pandemic H1N1 viruses can employ additional mechanisms lined to stress and anxiety during the course of infection.

Availability of global transcriptomic data of host response to pandemic and non-pandemic (seasonal) influenza provides a unique opportunity to unravel the additional mechanisms which lead to success of pandemic influenza in host infection. Furthermore, recent developments in network analysis, Gene Ontology (GO) classification, and GO network offer new tools to discover the biological consequences of the observed alterations in gene expression profile.

The most comprehensive available data in the subject of host immunity against pandemic influenza is provided by Rowe et al., (2010). In the mentioned study, using ferret as experimental infection model, global gene expression profile of host immune response 
against pandemic 2009-H1N1 A/California/07/2009 and seasonal A/Brisbane/59/2007 were obtained. (Rowe et al. 2010).

CCL2, CCL8, CXCL7 and CXCL10 (chemokines) along with the majority of interferonstimulated genes were expressed early, correlated to lung pathology, and abruptly decreased expression on day 7 following infection of A/California/07/2009. They propose that lung pathology in humans occurs during the innate phase of host immunity and a delay or failure to switch to the adaptive phase may contribute to morbidity and mortality during severe 2009-H1N1 infections (Rowe et al. 2010). This data can be further analyzed in the context of network and GO annotations to dig into mechanisms underlying pandemic infection.

The concept of network-based medicine is based on this fact that rarely, a disease is a consequence of a single gene abnormality (Barabási et al. 2011). Network analysis by aggregating available information in the frame of networks provides the unique opportunities to unravel gene/protein interactions, correlations, and significant interactions which would be otherwise undiscovered and unexplored (Cruts et al. 2012). It should be noted that molecular components in a cell are functionally dependent; consequently, construction of statistically significant networks is much closer to the reality which happens within a cell. Network based analysis of gene expression data elaborates systematic view on disease emergence and also has been considered as an effective tool in gene discovery (Barabási et al. 2011; Stuart et al. 2003; Calvano et al. 2005; Wu et al. 2008). Network architecture (topology) can highlight the key genes (genes with higher number of interactions) as well as genes which connect different networks (Ebrahimie et al. 2014). Different approaches have been utilized for network discovery within a set of genes such as text (literature mining), co-expression analysis, promoter analysis, microRNA prediction, as well as visualizing GO interactions (Markowetz and Spang 2007; Stuart et al. 2003; Obayashi et al. 2013; Zhang and Horvath 2005; Ruan et al. 2010; Nikitin et al. 2003; Bakhtiarizadeh et al. 2014; Hosseinpour et al. 2012; Fruzangohar et al. 2014).

Similar to network analysis, GO analysis adds a new dimension in biological knowledge discovery from the bulk of differentially expressed genes (Fruzangohar et al. 2014; Fruzangohar et al. 2013). GO classification of significant up/downregulated genes is the first step in functional genomic analysis to interpret the transcriptomic data. GO enrichment analysis classifies genes/proteins based on the controlled universal vocabulary in 3 major categories of Biological Process, Molecular Function, and Cellular Component which greatly helps the researchers to reach the similar functional annotation language and understanding. Finding the key GO groups and selection of genes based on the significant GOs are novel and 
reliable approaches in gene discovery as the selected genes are central in meaningful biological processes (Fruzangohar et al. 2013). Furthermore, comparison of GO enrichment of a given sample verses GO distribution of whole genome (as reference) by Fisher exact test (hyper-geometry approach) illustrates the differential functional groups in a particular sample. Furthermore, recent developments in constructing GO networks provide unique possibility to investigate the transcriptome in the context of functional interactions between different GO classes (Fruzangohar et al. 2014; Fruzangohar et al. 2013).

The aim of this study was to compare the differential effects of pandemic and non-pandemic influenza viruses on host functional genomics, in particular nervous system, in the context of GO enrichment, gene networks and regulatory mechanisms. To this end, microarray data of the effects of the pandemic virus, A/California/07/2009, and non-pandemic virus, A/Brisbane/59/2007, on Canis lupus (host) was employed. Up and downregulated genes, during the course of infection with pandemic or seasonal viruses, were computed and significantly altered genes related to nervous systems were determined. A variety of computational biology techniques including subnetwork discovery, network construction, GO enrichment, and GO network were utilized to shed light on the underpinning mechanisms of pandemic influenza and host interaction. For the first time, we found that apart from cytokine/chemokine storm and neuraminidase enzyme dysfunction, pandemic influenza activates other neuronal disorder pathways. Modulation of these genes can cause neuronal disorder in patient with pathogenic H1NI influenza virus. 


\section{Materials ant methods}

\section{Data collection}

Affymetrix-based microarray data of ferret, as mammalian model, after injection with seasonal (non-pandemic, A/Brisbane/59/2007) and pandemic influenza (A/California/07/2009) (Rowe et al. 2010) were downloaded from GEO repository of NCBI database (GEO number: GSE17079). In this experiment RNA was extracted from lung tissue of ferret and the host immune responses during the infection with seasonal A/Brisbane/59/2007 and 2009-H1N1 A/California/07/2009 were profiled by Affymetrix Gene Chip Canine Genome 2.0 Array.

\section{Expression analysis}

The plan of the original experiment by Rowe et al., (2010) was in time series frame. In this study, this plan disregarded and the data pooled together to generate two separate treatments: (1) infection with pandemic (A/California/07/2009 strain), and (2) infection with nonpandemic (A/Brisbane/59/2007 strain). Each treatment had 15 replicates (expression CEL files). The employed analytical scheme is presented in Figure 1.

We normalized the downloaded CEL files of 3 ' expression array by Expression Console software (Affymetrix, USA) based on RMA (Robust Multichip Analysis) algorithm as described previously (Hosseinpour et al. 2012; Alisoltani et al. 2014). Two sample Baysian ttest was used to select the genes with significant differential expression at $p=0.05$ between two treatments [infected host with pandemic verses non-pandemic (seasonal) virus]. It has been discussed that Baysian based statistics have better performance with consistent Type I error rates, compared to the other methods (Fox and Dimmic 2006; Baseri et al. 2011). In addition to statistical significance, we also calculated Symmetric Fold Change (SFC). SFC represents upregulation with positive and downregulation with negative values. Analyses carried out by Flexarray package (Mc Gill University, Canada) as described previously (Hosseinpour et al. 2012; Alisoltani et al. 2014). Finally, genes with significant differential expression $(\mathrm{p}=0.05)$ and $\mathrm{SPF}>+2$ or $\mathrm{SPF}<-2$ were selected as upregulated/downregulated genes.

Based on the above mentioned characteristics, we found 23 downregulated genes $(\mathrm{p}=0.05$, SPF < -2) as well as upregulated 127 genes. Upregulated and downregulated genes were further investigated based on literature, available databases [Uniprot (http://www.uniprot.org/) and Gen Cards (http://www.genecards.org/) (Safran et al. 2002)] as well as GO classification using Comparative GO web application (Fruzangohar et al. 2013) to 
illustrate the ones which possibly are involved in neuronal disorders and exuberant cytokine responses. As it has been discussed in results, 4 downregulated genes (out of total 23 downregulated) and 27 upregulated genes (out of total 127 upregulated) were related to nervous system. These genes, particularly 4 downregulated genes, were used for further GO and network analysis .

\section{Subnetwork discovery and construction of pandemic influenza-associated nervous gene network}

In addition to the common expression analysis (described above), novel approaches of subnetwork discovery and network analysis were used to investigat whether neuronal disorder related up/downregulated genes can contribute in generation of statistically significant neuronal subnetworks or not.

We used RESNET database of Pathway Studio 10 (Elsevier) (Nikitin et al. 2003) which is an enriched database of mammalian gene/protein/small RNA interaction. The database contained new aliases for human genes, miRNAs, other non-coding RNAs as well as entries from other mammals. Extensive literature mining and literature based rule discovery by MedScan natural language processing (Novichkova et al. 2003) as well as microRNA target prediction and more importantly, the developed statistics for determining statistically significant (such as Fisher exact test) based on Gene Set Enrichment (GSE) approach (Subramanian et al. 2005) provided the opportunity to further investigation of significantly interactive networks within the altered genes by Pathway Studio Package. Furthermore, database is not restricted to a particular interaction and contains a wide range of interactions including promoter binding, mol transport, regulation, expression, protein modification, binding, mol synthesis, chemical reaction, direct regulation, miRNA effect, and small molecule (Nikitin et al. 2003). GSE is a robust method in detection of statistically significant subnetworks which up/downregulated genes can generate (Subramanian et al. 2005; Ebrahimie et al. 2014). Using the imported list of genes/miRNAs as input, GSE statistically examines the enrichment of different subnetworks within the collection of networks (gathered by literature mining in RESNET database of Pathway Studio ) at $\mathrm{p}=0.05$ using reliable statistics such as Fisher's exact test.

To construct regulatory gene network, neighbor joining algorithm at expansion $=1$ was used to link network elements (entities) based on different deposited relationships at RESNET database and up/downregulated genes as inputs as described previously (Hosseinpour et al. 2012; Alisoltani et al. 2014). Both upstream and downstream were selected as directions of 
each entity. A range of entities such as small molecules, cell process, pathogenesis, functional class as well as various types of relation such as expression, regulation, binding, moltransport, miRNA effect, etc. were considered to provide a comprehensive approach of influenza related pathways. The excel format of each network, containing all relations and entities of the network were recorded and presented as supplementary files.

\section{GO regulatory network construction}

In addition to the above mentioned networks, using statistically significant up/downregulated genes, we predicted a novel types of regulatory networks based on GO interactions using Comparative GO (http://turing.ersa.edu.au/BacteriaGO (Fruzangohar et al. 2014). In this type of network, instead of investigating relationships between genes, the genes transform to GO terms of Biological Process. Then, regulatory relationships were constructed between GOs (of Biological Processess) based on interactions extracted from Gene Ontology database (http://www.geneontology.org/) (Ashburner et al. 2000; Consortium 2004). The extracted relationships were deposited in internal database of Comparative GO portal (Fruzangohar et al. 2014; Fruzangohar et al. 2013). For the given gene sample of up/downregulated genes of neuronal-related genes, Comparative GO built a GO DAG (Directed AcyclicGraph) network, based on regulatory relationships. Then, in order to infer new relationships from available relationships, the initial GO was expanded to include new GO nodes interacting with parental nodes (Fruzangohar et al. 2014). The GO interaction network was visualized by Cytoscape plugin (Shannon et al. 2003) implemented in Comparative GO portal (Fruzangohar et al. 2014).

An important note regarding GO network is that GO networks incorporates alternative splicing in the network, as a GO with either more genes or more transcripts has the bigger size circle (diameter) compared to the GOs with less number of genes and alternative transcripts. It should be noted that the higher number of splicing indicates more activity and can be assumed as higher index of importance.

\section{Comparison the GO distribution of a sample verses genome distribution}

We compared (at $\mathrm{p}=0.05$ ) the GO enrichment of up/downregulated gene samples and their alternative transcripts verses genome using hyper-geometric distribution approach by Comparative GO web application (Fruzangohar et al. 2013). This analysis helps us to investigate the specific functions/pathways that our gene sample in involved in GO terms of biological process, molecular function, and cellular component. Hyper-geometry is based on 
Fisher exact test to find the differential distribution of GO enrichment within our sample compared to genome (as reference/control). 


\section{Results}

\section{Monitoring the differential response of host system to pandemic influenza compared to seasonal (non-pandemic) influenza}

The results showed that pandemic influenza (A/California/07/2009) infection differentially modulates 31 host genes (27 genes up and 4 genes downregulated) associated with nervous system whereas seasonal influenza (A/Brisbane/59/2007) was not able to alter them. The list of the downregulated genes and their descriptions regarding nervous system are presented in Table 1. Interestingly, these genes play important roles in neuronal communication and regulation such as neuronal differentiation, neuronal plasticity, neurite and filopodia outgrowth, synapse formation, establishment and maintenance of neuronal connections (Table 1).

\section{Subnetwork discovery: a clue for analyzing differential impact of pandemic influenza} on host system in comparison to non-pandemic influenza

It is possible that each gene acts independently, but commonly, the genes interact with each other and form subnetworks. These subnetworks join together based on the shared elements (commonly transcription factors and microRNAs) and form the networks. Consequently, the first step in network analysis is subnetwork discovery which is finding the statistically significant subnetworks within the list of differentially expressed genes. We investigated subnetworks using a range of interactions such as miRNA interaction, direct and indirect regulation, chemical interaction to increase the chance of discovery of activated subnetworks. Statistically significant subnetworks which can be generated by upregulated genes are presented in Supplementary 1. Mitogen-activated protein kinase, calcium-independent protein kinase C, and SP1-interacting genes are important subnetworks. SP1 was the major transcription factor for many genes regulations such as NR5A1, FN1, IRF1, and NKX2-1.

In this study, our attention was majorly paid to the downregulated genes. Statistically significant subnetworks which can be generated by downregulated genes are presented in Table 2.

As presented in Table 2, microRNAs play the key role in forming the subnetworks of downregulated genes. In particular, microRNAs such as MIR367, MIR15B, MIR128, and MIR325 cause significant subnetworks which interact with proteins such as GPM6A, EVI5, PCDHAC2, and ARPP21. Subnetworks of MIR367, MIR15B, and MIR128 are presented in 
Figure 2. Interestingly, EVI5 contributes in two microRNA subnetworks and is under the control of MIR367 and MIR128. It can be stated that when a gene is under control of more regulators, it possibly play key functions. As presented in Table 1, EVI5 commonly has expression in brain and adrenal.

\section{Network analysis of host neuronal related genes specific to pandemic influenza infection}

Network analysis carried out to find the possible networks of host up and down which specifically are activate during pandemic influenza infection. One of the key benefits of network prediction is finding the central network genes (hubs). These hubs have the highest number of interactions with other genes which commonly indicates the higher importance/function of these genes.

The predicted network based on neighbor joining algorithm is presented at Figure 3 . The relations of this network and their references are presented in Supplementary 2. Network shows that apart from some genes such as CCBL1, RNF10, SF1 and LAPTM5, the others had complex interactions together. According to the interaction network of Figure 3, FN1 is an upregulated gene with the high number of interactions with the other genes; along with IRFI, NKX2-1, and NR5A1 genes. Interestingly, upregulation of FN1 gene can lead to disorders in many processes (Villani et al. 2007).

Another important subject in gene networking was the interactions between the nodes. The crosstalk between six nodes is presented in Figure 4A and Supplementary 3 demonstrating that $N C O A 3$ and $T G F B 2$ join the 4 other nodes together. The expression target analysis between these genes (Figure 4B and Supplementary 4) showed that the SP1 is in the center of interactions.

\section{Induction of severe cytokine/chemokine storm related network by pandemic influenza}

Further study of genes which particularly induce by pandemic influenza (Table 1) showed that in addition to neuronal disorders, some of these genes are involved in cytokine/chemokine storm as well. It seems that there is a direct crosstalk between genes involved in cytokine/chemokine storm (after virus infection) and the genes involved in neuronal disorders as upregulated genes of YWHAE, AES, and IRFI and downregulated gene of EVI5 are shared. These genes can cause cytokine/chemokine storm on one hand and cause neuronal disorders the other hand. Crosstalk between genes involved in neuronal disorders and cytokine storm is presented at Figure 5. Interestingly, some genes of cytokine storm process such as HNRNPM, CDK9, TSC22D1, and KPNA2 directly interact with the genes 
involved in neuronal disorders (Figure 5). Relations of this network and its references are presented in Supplementary 5.

GO regulatory network of host genes which merely downregulate by pandemic influenza compared to seasonal (non-pandemic) influenza

Figure 6 shows GO regulatory network of host genes which merely downregulate by pandemic influenza (compared to seasonal non-pandemic influenza). GO regulatory network represent 3 types of information: (1) regulatory relationships between GO terms and their associated genes presented by directed edges of the circles, (2) enrichment (magnitude) level of each GO term which is presented by diameter of circles, and (3) finally, the genes linked to each GO term (Fruzangohar et al. 2014). Furthermore, network topology highlighted the GOs and their associated genes which have the highest number of interactions with other GOs. Based on the network topology, these genes locate on the centre of network. As higher network interaction can be assumed as higher importance index, GO and its corresponding genes, located at the centre of the network can be assumed to play more central regulatory function in the process.

The predicted GO network (Figure 6) shows that 2 functional groups of "positive regulation of filopodium assembly" and "positive regulation of RabGTPase activity" are located in the centre of network and have the highest number of connections (interactions) with the other GOs. Interestingly, "positive regulation of filopodium assembly" contains GPM6A. GPM6A is remarkably downregulated (more than 5 fold change) in host after pandemic influenza infection (Table 1) whereas non-pandemic influenza could not downregulate this gene. GO harboring GPM6A has interactions with other GOs including synapse assembly, neuron projection, and neural retina development. GTPase activity is also located at the centre of network and has considerable number of interactions with other GOs such as synapse assembly and neuron projection (Figure 6).

Comparison of GO distribution of host neuronal related genes which solely downregulate by pandemic influenza

Comparison of GO enrichment of downregulated genes and their alternative transcripts verses GO distribution of whole genome by Fisher exact test (hyper-geometry) in 3 levels of "Biological Process", "Molecular Function", and "Cellular Components" is presented at Figure 7. 
Interestingly, in the term of Biological Process, significantly downregulated functions by pandemic influenza (and their corresponding genes) were related to GO terms such as synapse assembly, positive regulation of filopodium assembly, neuron projection, and neural development (Figure 7A). Due to remarkable downregulation of these genes after pandemic infection, compared to non-pandemic infection, it can be concluded that the host infected with pandemic influenza has significantly lower synapse assembly, positive regulation of filopodium assembly, neuron projection, and neural development.

In "Molecular Function" term, downregulated genes (and their corresponding transcripts) enriched GOs such as calcium ion binding, calcium channel activity, and GTPase activity (Figure 7B). Regarding down regulation of these genes after pandemic influenza infection, infected host with pandemic influenza has lower calcium ion binding, calcium channel activity, nucleotide binding activity. Regarding the key role of calcium signaling and calcium channel activity in understanding the message and rapid response, it can be concluded that infected cells with pandemic influenza have lower efficiency in signal transduction, understanding response, and regulating host immune response.

In "Cellular Component, downregulated genes belong to the neuron cell body, integral membrane, membrane, and filipodum (Figure 7C). In other words, pandemic influenza targets and decreases the integral membrane and neuron body and hinders their development. 


\section{Discussion}

While seasonal influenza has a mild infection with a low mortality, pandemic influenza is able to transmit easily between people, spread globally, with high pathogenicity and mortality. As example, 2009 H1N1 influenza A spread globally to over 116 countries. The understanding layer of the differential and successful evolution of pandemic influenza is yet to be known. The evolution of pandemic has occurred in respect to host response system. Consequently, the study of genes modulated in host transcriptome by pandemic influenza compared to seasonal nonpandemic influenza can provide valuable information in pandemic route of evolution. While up to now, more attention has been paid to the study of upregulated genes, this study documents the importance of analyzing downregulated genes in unraveling host response and pathogen evolution. It should be noted that modulation of a gene in host transcriptome can be a positive (as the host defense mechanism) or negative (as the host-breaking mechanism by pathogen).

In this study, we showed that pandemic influenza, significantly downregulate some genes related to neural disorders, in particular GPM6A. It has been recently reported that mutation in GPM6A can result in claustrophobia (El-Kordi et al. 2013). Regarding the polygenic nature of neural disorders, the fact that GPM6A is able to cause claustrophobia disorder highlights its importance. The GPM6A encodes the glycoprotein M6A that associated with the differentiation and neuronal migration of neurons derived from undifferentiated human stem cells (Michibata et al. 2009). Association of the GPM6A with the subgroup of schizophrenia patients reinforces the key role of this gene in regulation of CNS (Boks et al. 2008). Another study showed that the expression of this gene downregulates in chronic stress (Cooper et al. 2009). Therefore it can be concluded that pandemic influenza virus infection may cause chronic stress by GPM6A dysfunction. Because of the key role of this gene in neuronal disorders, downregulation of this gene may be the main reason for neurological disease after pandemic influenza infection. Another downregulated gene is the EVI5 gene that encodes the ecotropic viral integration site5 protein or NB4S (Roberts et al. 1998). The EVI5 has main role in mitosis and cell cycles (Eldridge et al. 2006), and a potential risk factor in multiple sclerosis (D'Netto et al. 2009).

Other downregulated genes, PCDHAC2 and ARPP21D, were connected together by MIR15B and have major roles in nervous system functions. PCDHAC2 is involved in the modulation of synaptic transmission and generation of specific synaptic connections (Frank and Kemler 2002). $A R P P 21 D$, encodes the $21 \mathrm{KD}$ cAMP regulated phosphoprotein. This protein is enriched in 
cerebellar cortex of brain and has main roles in CNS function and diseases such as Alzheimer's disease (Hipfel et al. 2003). PCDHAC2 interact in the network with PSAP (upregulated gene) by MIR19A and with IRF1 (upregulated gene) through MIR17. PSAP encodes Saposin C proteinand has several neuronal effects, including neuronal outgrowth stimulation, neuron preservation, and nerve regeneration enhancement (Chu et al. 2005). IRF1 is a transcription factor with a main role in CNS and involved in the pathogenesis of multiple sclerosis and experimental autoimmune encephalomyelitis (Ren et al. 2011). Also, the downregulated gene, $A R P P 21 D$, interacted in the network with upregulated MARK2 (by MIR214) that involves in regulation of dendrites development in hippocampal neurons (Terabayashi et al. 2007).

Within the upregulated genes by pandemic influenza, FN1 and IRFI had key positions and more interactions. FN1 encodes fibronectin1 protein that has main roles in induction of neuronal adhesion proteins and neurite outgrowth (Choung et al. 2002). IRF1 is another upregulated gene which encodes for interferon regulatory factor 1 that is involved in the pathogenesis of multiple sclerosis and experimental autoimmune encephalomyelitis (Ren et al. 2011).

Downregulated genes were further investigated by three quality based functional genomics analysis (network discovery, GO enrichment, and GO network) to unravel the molecular networks and functional groups which these genes can attend, providing a more reliable method for identifying the central genes and study of systems biology. As quality based analyses methods, these approaches provided new knowledge regarding the interaction between genes and prevents false positive significant expression (quantity based method) which is the common problem in expression analysis (Lawrence et al. 2013). It should be noted that expression level alone cannot be announced as the sole criterion of gene significance whereas some genes with lower expression levels (such as transcription factors and microRNAs) play a prominent role in systems biology (Fruzangohar et al. 2014; Fruzangohar et al. 2013; Mahdi et al. 2013; Bakhtiarizadeh et al. 2013).

In particular, GO regulatory network showed high performance and pointed out (GOs containing GPM6A and GTPase as the central nodes interacting with important GOs of synapse assembly, neuron projection, and neural retina development. Compared to the common gene networks, GO regulatory networks can identify the key functional genomics based interactions in a broader sense (Fruzangohar et al. 2014). Classification of a large number of genes in a small number of GO classes and visualizing the GO networks can remarkably decrease the network complexity 
and, more importantly, offers a new approach for gene selection by considering the genes which contribute to central nodes in GO regulatory networks

Downregulating GOs related to synapse assembly, calcium binding and calcium channel activity, neuron projection, and neuron membrane development by pandemic influenza is a major finding. Neural cell division does not progress after birth in the majority of mammals. However, interestingly, neuron development is an ongoing process where the neural membrane develops dendritic projection. More developed dendritic projection induce more advanced dendritic network which allows better communication and neural signal processing between neurons. In diseases such as depression, a less developed neural (dendritic) network is a common phenomenon. Calcium plays important regulatory roles in all brain activities such releasing the majority of neurotransmitters, long term memory, and development of synaptic connections (Armstrong and Hille). Calcium transportation occurs via calcium channels whereas in neural disorders, less activity of calcium channels is commonly observed (Armstrong and Hille). GTPase modulate the neural signals in dendretic junctions (Hille 1992). Both GTP and $\mathrm{Ca}^{++}$ related activities function in generation and modulation of effective neural signals.

Interestingly, pandemic influenza targets theses key players (calcium channels, synaptic projection, and neural membrane development) to inference neural development and synaptic transmission. In simple words, pandemic influenza makes the host less neurologically reactive and possibly depressive. In this manner, the host cannot effectively react to influenza infection. This can be assumed as one of the reasons of the observed depression during influenza infection. It should be noted that the non-pandemic (seasonal) has not this CNS-related capability.

This study has high potential to be used by clinicians. Due to crosstalk between pandemic influenza and CNS dysfunction diseases such as depression, Alzheimer's disease, claustrophobia, GPM6A and GTPase can be further investigated as therapeutic drugs for treatments of patients with severe pandemic influenza. Low expression level of genes/proteins such as GPM6A, EV15, ARPP21, PCDHAC2, and reversely, high level of microRNAs such as MIR367, MIR128-1, and MIR15B can be used for prognosis of neuronal disorders in the patients with pandemic influenza virus.

\section{Conclusion}


In conclusion, the results of this study showed that pandemic influenza virus is evolved differentially, (compared to non-pandemic influenza), to interference neural development and synaptic transmission trough downregulations of key proteins of calcium channels, synaptic projection, and neural membrane. The neuronal disorder network has interactions and crosstalk with previously known cytokine/chemokine storm pathway.

Virus-associated central nervous system (CNS) diseases have mainly been studied in terms of cytokine/chemokine responses and neuraminidase enzyme dysfunction. The involvement of the other pathways is not yet discovered. The developed approach offers a new way to search for other possibilities to unravel unknown pathways in CNS dysfunction by utilizing global transcriptomic data, network and GO analysis.

\section{Acknowledgment}

This study is supported based on 2 projects of Australian Centre for International Agricultural Research (ACIAR) (project number AH/2006/050 and project number AH/2010/039). We would like to greatly thank Dr. Manijeh Mohammadi-Dehcheshmeh and Dr. Mario Fruzangohar from School of Agriculture, Food, and Wine, The University of Adelaide for their technical help and valuable comments during analysis and manuscript preparation. 


\section{References}

Alisoltani A, Fallahi H, Ebrahimi M, Ebrahimi M, Ebrahimie E (2014) Prediction of Potential Cancer-Risk Regions Based on Transcriptome Data: Towards a Comprehensive View. PloS one 9 (5):e96320

Armstrong CM, Hille B Voltage-Gated Ion Channels and Electrical Excitability. Neuron 20 (3):371-380. doi:10.1016/S0896-6273(00)80981-2

Ashburner M, Ball CA, Blake JA, Botstein D, Butler H, Cherry JM, Davis AP, Dolinski K, Dwight SS, Eppig JT (2000) Gene Ontology: tool for the unification of biology. Nature genetics 25 (1):25-29

Bakhtiarizadeh MR, Moradi-Shahrbabak M, Ebrahimie E (2013) Underlying functional genomics of fat deposition in adipose tissue. Gene 521 (1):122-128. doi:10.1016/j.gene.2013.03.045

Bakhtiarizadeh MR, Moradi-Shahrbabak M, Ebrahimie E (2014) Transcriptional regulatory network analysis of the over-expressed genes in adipose tissue. Genes \& Genomics 36 (1):105-117

Barabási A-L, Gulbahce N, Loscalzo J (2011) Network medicine: a network-based approach to human disease. Nature Reviews Genetics 12 (1):56-68

Baseri S, Towhidi M, Ebrahimie E (2011) A modified efficient empirical bayes regression model for predicting phenomena with a large number of independent variables and fewer observations; examples of its application in human disease, protein bioinformatics, and microarray gene expression profiling. Advanced Studies in Biology 3:181-204

Boks MP, Hoogendoorn M, Jungerius BJ, Bakker SC, Sommer IE, Sinke RJ, Ophoff RA, Kahn RS (2008) Do mood symptoms subdivide the schizophrenia phenotype? Association of the GMP6A gene with a depression subgroup. Am J Med Genet B Neuropsychiatr Genet 147B (6):707-711. doi:10.1002/ajmg.b.30667 [doi]

Calitri C, Gabiano C, Garazzino S, Pinon M, Zoppo M, Cuozzo M, Scolfaro C, Tovo PA (2010) Clinical features of hospitalised children with 2009 H1N1 influenza virus infection. Eur J Pediatr 169 (12):1511-1515. doi:10.1007/s00431-010-1255-y [doi]

Calvano SE, Xiao W, Richards DR, Felciano RM, Baker HV, Cho RJ, Chen RO, Brownstein BH, Cobb JP, Tschoeke SK, Miller-Graziano C, Moldawer LL, Mindrinos MN, Davis RW, Tompkins RG, Lowry SF, Large Scale Collab. Res P, Host Response to I (2005) A network-based analysis of systemic inflammation in humans. Nature 437 (7061):1032-1037. doi:http://www.nature.com/nature/journal/v437/n7061/suppinfo/nature03985 S1.html

Choung PH, Seo BM, Chung CP, Yamada KM, Jang JH (2002) Synergistic activity of fibronectin and fibroblast growth factor receptors on neuronal adhesion and neurite extension through extracellular signal-regulated kinase pathway. Biochem Biophys Res Commun 295 (4):898-902. doi:S0006291X0200774X [pii]

Chu Z, Sun Y, Kuan CY, Grabowski GA, Qi X (2005) Saposin C: neuronal effect and CNS delivery by liposomes. Ann N Y Acad Sci 1053:237-246. doi:1053/1/237 [pii]

10.1196/annals.1344.021 [doi]

Consortium GO (2004) The Gene Ontology (GO) database and informatics resource. Nucleic acids research 32 (suppl 1):D258-D261

Cooper B, Fuchs E, Flügge G (2009) Expression of the Axonal Membrane Glycoprotein M6a Is Regulated by Chronic Stress. PLoS One 4 (1):e3659. doi:10.1371/journal.pone.0003659

Cruts M, Theuns J, Van Broeckhoven C (2012) Locus-specific mutation databases for neurodegenerative brain diseases. Human mutation 33 (9):1340-1344

D'Netto MJ, Ward H, Morrison KM, Ramagopalan SV, Dyment DA, DeLuca GC, Handunnetthi L, Sadovnick AD, Ebers GC (2009) Risk alleles for multiple sclerosis in multiplex families. Neurology 72 (23):1984-1988. doi:72/23/1984 [pii]

10.1212/WNL.0b013e3181a92c25 [doi] 
Donaldson L, Rutter PD, Ellis BM, Greaves FEC, Mytton OT, Pebody RG, Yardley IE (2009) Mortality from pandemic A/H1N1 2009 influenza in England: public health surveillance study. BMJ 339. doi:10.1136/bmj.b5213

Ebrahimie M, Esmaeili F, Cheraghi S, Houshmand F, Shabani L, Ebrahimie E (2014) Efficient and Simple Production of Insulin-Producing Cells from Embryonal Carcinoma Stem Cells Using Mouse Neonate Pancreas Extract, As a Natural Inducer. PloS one 9 (3):e90885

El-Kordi A, Kästner A, Grube S, Klugmann M, Begemann M, Sperling S, Hammerschmidt K, Hammer C, Stepniak B, Patzig J (2013) A single gene defect causing claustrophobia. Translational psychiatry 3 (4):e254

Eldridge AG, Loktev AV, Hansen DV, Verschuren EW, Reimann JD, Jackson PK (2006) The evi5 oncogene regulates cyclin accumulation by stabilizing the anaphase-promoting complex inhibitor emi1. Cell 124 (2):367-380. doi:S0092-8674(05)01323-1 [pii]

10.1016/j.cell.2005.10.038 [doi]

Fatemi SH, Pearce DA, Brooks Al, Sidwell RW (2005) Prenatal viral infection in mouse causes differential expression of genes in brains of mouse progeny: A potential animal model for schizophrenia and autism. Synapse 57 (2):91-99. doi:10.1002/syn.20162

Fox RJ, Dimmic MW (2006) A two-sample Bayesian t-test for microarray data. BMC Bioinformatics 7:126. doi:10.1186/1471-2105-7-126

Frank M, Kemler R (2002) Protocadherins. Curr Opin Cell Biol 14 (5):557-562. doi:S0955067402003654 [pii]

Fruzangohar M, Ebrahimie E, Adelson DL (2014) Application of Global Transcriptome Data in Gene Ontology Classification and Construction of a Gene Ontology Interaction Network. bioRxiv

Fruzangohar M, Ebrahimie E, Ogunniyi AD, Mahdi LK, Paton JC, Adelson DL (2013) Comparative GO: A web application for comparative gene ontology and gene ontology-based gene selection in bacteria. PloS one 8 (3):e58759

Hille B (1992) G protein-coupled mechanisms and nervous signaling. Neuron 9 (2):187-195. doi:http://dx.doi.org/10.1016/0896-6273(92)90158-A

Hipfel R, Hanes J, Von Der Kammer H, Pohlner J (2003) Camp-regulated phosphoprotein for diagnostic and therapeutic use in neurodegenerative diseases. Google Patents,

Hosseinpour B, Hajihoseini V, Kashfi R, Ebrahimie E, Hemmatzadeh F (2012) Protein Interaction Network of Arabidopsis thaliana Female Gametophyte Development Identifies Novel Proteins and Relations. PLoS One 7 (12):e49931. doi:10.1371/journal.pone.0049931 [doi]

PONE-D-11-25935 [pii]

Lawrence MS, Stojanov P, Polak P, Kryukov GV, Cibulskis K, Sivachenko A, Carter SL, Stewart C, Mermel $\mathrm{CH}$, Roberts SA (2013) Mutational heterogeneity in cancer and the search for new cancerassociated genes. Nature

Lee N, Wong CK, Chan PK, Lindegardh N, White NJ, Hayden FG, Wong EH, Wong KS, Cockram CS, Sung JJ, Hui DS (2010) Acute encephalopathy associated with influenza A infection in adults. Emerg Infect Dis 16 (1):139-142. doi:10.3201/eid1601.090007 [doi]

Mahdi LK, Ebrahimie E, Adelson DL, Paton JC, Ogunniyi AD (2013) A transcription factor contributes to pathogenesis and virulence in Streptococcus pneumoniae. PloS one 8 (8):e70862

Markowetz F, Spang R (2007) Inferring cellular networks-a review. BMC bioinformatics 8 (Suppl 6):S5

Maurizi CP (1985) Why was the 1918 influenza pandemic so lethal? The possible role of a neurovirulent neuraminidase. Medical Hypotheses 16 (1):1-5. doi:http://dx.doi.org/10.1016/0306-

$\underline{9877(85) 90034-9}$ 
Michibata H, Okuno T, Konishi N, Kyono K, Wakimoto K, Aoki K, Kondo Y, Takata K, Kitamura Y, Taniguchi $T$ (2009) Human GPM6A is associated with differentiation and neuronal migration of neurons derived from human embryonic stem cells. Stem Cells Dev 18 (4):629-639. doi:10.1089/scd.2008.0215 [doi]

Mills CE, Robins JM, Lipsitch M (2004) Transmissibility of 1918 pandemic influenza. Nature 432 (7019):904-906. doi:nature03063 [pii]

10.1038/nature03063 [doi]

Mori I, Hossain MJ, Takeda K, Okamura H, Imai Y, Kohsaka S, Kimura Y (2001) Impaired Microglial Activation in the Brain of IL-18-Gene-Disrupted Mice after Neurovirulent Influenza A Virus Infection. Virology 287 (1):163-170. doi:http://dx.doi.org/10.1006/viro.2001.1029

Nikitin A, Egorov S, Daraselia N, Mazo I (2003) Pathway studio-the analysis and navigation of molecular networks. Bioinformatics 19 (16):2155-2157. doi:10.1093/bioinformatics/btg290

Novichkova S, Egorov S, Daraselia N (2003) MedScan, a natural language processing engine for MEDLINE abstracts. Bioinformatics 19 (13):1699-1706

Obayashi T, Okamura Y, Ito S, Tadaka S, Motoike IN, Kinoshita K (2013) COXPRESdb: a database of comparative gene coexpression networks of eleven species for mammals. Nucleic acids research 41 (D1):D1014-D1020

Ren Z, Wang Y, Liebenson D, Liggett T, Goswami R, Stefoski D, Balabanov R (2011) IRF-1 signaling in central nervous system glial cells regulates inflammatory demyelination. J Neuroimmunol 233 (1-2):147-159. doi:S0165-5728(11)00002-6 [pii]

10.1016/j.jneuroim.2011.01.001 [doi]

Roberts T, Chernova O, Cowell JK (1998) NB4S, a member of the TBC1 domain family of genes, is truncated as a result of a constitutional $t(1 ; 10)(p 22 ; q 21)$ chromosome translocation in a patient with stage 4S neuroblastoma. Hum Mol Genet 7 (7):1169-1178. doi:ddb145 [pii]

Rowe T, Leon AJ, Crevar CJ, Carter DM, Xu L, Ran L, Fang Y, Cameron CM, Cameron MJ, Banner D, Ng DC, Ran R, Weirback HK, Wiley CA, Kelvin DJ, Ross TM (2010) Modeling host responses in ferrets during A/California/07/2009 influenza infection. Virology 401 (2):257-265. doi:S00426822(10)00129-7 [pii]

10.1016/j.virol.2010.02.020 [doi]

Ruan J, Dean AK, Zhang W (2010) A general co-expression network-based approach to gene expression analysis: comparison and applications. BMC systems biology 4 (1):8

Safran M, Solomon I, Shmueli O, Lapidot M, Shen-Orr S, Adato A, Ben-Dor U, Esterman N, Rosen N, Peter I (2002) GeneCards ${ }^{\mathrm{TM}}$ 2002: towards a complete, object-oriented, human gene compendium. Bioinformatics 18 (11):1542-1543

Shannon P, Markiel A, Ozier O, Baliga NS, Wang JT, Ramage D, Amin N, Schwikowski B, Ideker T (2003) Cytoscape: a software environment for integrated models of biomolecular interaction networks. Genome research 13 (11):2498-2504

Stuart JM, Segal E, Koller D, Kim SK (2003) A Gene-Coexpression Network for Global Discovery of Conserved Genetic Modules. Science 302 (5643):249-255. doi:10.1126/science.1087447

Subramanian A, Tamayo P, Mootha VK, Mukherjee S, Ebert BL, Gillette MA, Paulovich A, Pomeroy SL, Golub TR, Lander ES, Mesirov JP (2005) Gene set enrichment analysis: A knowledge-based approach for interpreting genome-wide expression profiles. Proceedings of the National Academy of Sciences of the United States of America 102 (43):15545-15550. doi:10.1073/pnas.0506580102

Tan K, Prerna A, Leo YS (2010) Surveillance of H1N1-related neurological complications. Lancet Neurol 9 (2):142-143. doi:S1474-4422(10)70015-6 [pii] 
10.1016/S1474-4422(10)70015-6 [doi]

Terabayashi T, Itoh TJ, Yamaguchi H, Yoshimura Y, Funato Y, Ohno S, Miki H (2007) Polarity-regulating kinase partitioning-defective 1 /microtubule affinity-regulating kinase 2 negatively regulates development of dendrites on hippocampal neurons. J Neurosci 27 (48):13098-13107.

doi:27/48/13098 [pii]

10.1523/JNEUROSCl.3986-07.2007 [doi]

Toovey S (2008) Influenza-associated central nervous system dysfunction: A literature review. Travel medicine and infectious disease 6 (3):114-124

Valleron AJ, Cori A, Valtat S, Meurisse S, Carrat F, Boelle PY (2010) Transmissibility and geographic spread of the 1889 influenza pandemic. Proceedings of the National Academy of Sciences of the United States of America 107 (19):8778-8781. doi:1000886107 [pii]

10.1073/pnas.1000886107 [doi]

Villani GR, Gargiulo N, Faraonio R, Castaldo S, Gonzalez YRE, Di Natale P (2007) Cytokines, neurotrophins, and oxidative stress in brain disease from mucopolysaccharidosis IIIB. Journal of neuroscience research 85 (3):612-622. doi:10.1002/jnr.21134

Wu X, Jiang R, Zhang MQ, Li S (2008) Network-based global inference of human disease genes. Molecular systems biology 4:189. doi:10.1038/msb.2008.27

Zhang B, Horvath S (2005) A general framework for weighted gene co-expression network analysis. Statistical applications in genetics and molecular biology 4 (1):1128 
Alisoltani A, Fallahi H, Ebrahimi M, Ebrahimi M, Ebrahimie E (2014) Prediction of Potential Cancer-Risk Regions Based on Transcriptome Data: Towards a Comprehensive View. PloS one 9: e96320

Armstrong CM, Hille B Voltage-Gated Ion Channels and Electrical Excitability. Neuron 20: 371-380

Ashburner M, Ball CA, Blake JA, Botstein D, Butler H, Cherry JM, Davis AP, Dolinski K, Dwight SS, Eppig JT (2000) Gene Ontology: tool for the unification of biology. Nature genetics 25: 25-29

Bakhtiarizadeh MR, Arefnejad B, Ebrahimie E, Ebrahimi M (2012) Application of functional genomic information to develop efficient EST-SSRs for the chicken (Gallus gallus). Genetics and Molecular Research 11: 1558-1574

Bakhtiarizadeh MR, Moradi-Shahrbabak M, Ebrahimie E (2013) Underlying functional genomics of fat deposition in adipose tissue. Gene 521: 122-128

Bakhtiarizadeh MR, Moradi-Shahrbabak M, Ebrahimie E (2014) Transcriptional regulatory network analysis of the over-expressed genes in adipose tissue. Genes \& Genomics 36: 105-117

Banerjee S, Neveu P, Kosik KS (2009) A coordinated local translational control point at the synapse involving relief from silencing and MOV10 degradation. Neuron 64: 871-884

Barabási A-L, Gulbahce N, Loscalzo J (2011) Network medicine: a network-based approach to human disease. Nature Reviews Genetics 12: 56-68

Barr IG, Komadina N, Hurt A, Shaw R, Durrant C, lannello P, Tomasov C, Sjogren H, Hampson AW (2003) Reassortants in recent human influenza $A$ and $B$ isolates from South East Asia and Oceania. Virus Res 98 : 35-44

Bartel DP (2009) MicroRNAs: Target Recognition and Regulatory Functions. Cell 136: 215-233

Baseri S, Towhidi M, Ebrahimie E (2011) A modified efficient empirical bayes regression model for predicting phenomena with a large number of independent variables and fewer observations; examples of its application in human disease, protein bioinformatics, and microarray gene expression profiling. Advanced Studies in Biology 3: 181-204

Boks MP, Hoogendoorn M, Jungerius BJ, Bakker SC, Sommer IE, Sinke RJ, Ophoff RA, Kahn RS (2008) Do mood symptoms subdivide the schizophrenia phenotype? Association of the GMP6A gene with a depression subgroup. Am J Med Genet B Neuropsychiatr Genet 147B: 707-711

Bouvier NM, Palese $P$ (2008) The biology of influenza viruses. Vaccine 26 Suppl 4: D49-53

Boyer LA, Lee TI, Cole MF, Johnstone SE, Levine SS, Zucker JP, Guenther MG, Kumar RM, Murray HL, Jenner RG, Gifford DK, Melton DA, Jaenisch R, Young RA (2005) Core Transcriptional Regulatory Circuitry in Human Embryonic Stem Cells. Cell 122: 947-956

Budefeld T, Tobet SA, Majdic G (2012) Steroidogenic factor 1 and the central nervous system. J Neuroendocrinol 24: 225-235

Calitri C, Gabiano C, Garazzino S, Pinon M, Zoppo M, Cuozzo M, Scolfaro C, Tovo PA (2010) Clinical features of hospitalised children with 2009 H1N1 influenza virus infection. Eur J Pediatr 169: 1511-1515

Calvano SE, Xiao W, Richards DR, Felciano RM, Baker HV, Cho RJ, Chen RO, Brownstein BH, Cobb JP, Tschoeke SK, Miller-Graziano C, Moldawer LL, Mindrinos MN, Davis RW, Tompkins RG, Lowry SF, Large Scale Collab. Res P, Host Response to I (2005) A network-based analysis of systemic inflammation in humans. Nature 437: 1032-1037

Chen K, Rajewsky N (2007) The evolution of gene regulation by transcription factors and microRNAs. Nat Rev Genet 8: 93-103

Choung PH, Seo BM, Chung CP, Yamada KM, Jang JH (2002) Synergistic activity of fibronectin and fibroblast growth factor receptors on neuronal adhesion and neurite extension through extracellular signal-regulated kinase pathway. Biochem Biophys Res Commun 295: 898-902

Chu Z, Sun Y, Kuan CY, Grabowski GA, Qi X (2005) Saposin C: neuronal effect and CNS delivery by liposomes. Ann N Y Acad Sci 1053: 237-246 
Ciment G, Ressler A, Letourneau PC, Weston JA (1986) A novel intermediate filament-associated protein, NAPA-73, that binds to different filament types at different stages of nervous system development. J Cell Biol 102: 246-251

Consortium GO (2004) The Gene Ontology (GO) database and informatics resource. Nucleic acids research 32: D258-D261

Cooper B, Fuchs E, Flügge G (2009) Expression of the Axonal Membrane Glycoprotein M6a Is Regulated by Chronic Stress. PLoS One 4: e3659

Cruts M, Theuns J, Van Broeckhoven C (2012) Locus-specific mutation databases for neurodegenerative brain diseases. Human mutation 33: 1340-1344

D'Netto MJ, Ward H, Morrison KM, Ramagopalan SV, Dyment DA, DeLuca GC, Handunnetthi L, Sadovnick AD, Ebers GC (2009) Risk alleles for multiple sclerosis in multiplex families. Neurology 72: 1984-1988

Deihimi T, Niazi A, Ebrahimi M, Kajbaf K, Fanaee S, Bakhtiarizadeh MR, Ebrahimie E (2012) Finding the undiscovered roles of genes: an approach using mutual ranking of coexpressed genes and promoter architecture-case study: dual roles of thaumatin like proteins in biotic and abiotic stresses. SpringerPlus 1: $1-10$

Dhillon H, Zigman JM, Ye C, Lee CE, McGovern RA, Tang V, Kenny CD, Christiansen LM, White RD, Edelstein EA, Coppari R, Balthasar N, Cowley MA, Chua S, Jr., Elmquist JK, Lowell BB (2006) Leptin directly activates SF1 neurons in the VMH, and this action by leptin is required for normal body-weight homeostasis. Neuron 49: 191-203

Donaldson L, Rutter PD, Ellis BM, Greaves FEC, Mytton OT, Pebody RG, Yardley IE (2009) Mortality from pandemic A/H1N1 2009 influenza in England: public health surveillance study. BMJ 339

Ebrahimi M, Aghagolzadeh P, Shamabadi N, Tahmasebi A, Alsharifi M, Adelson DL, Hemmatzadeh F, Ebrahimie E (2014) Understanding the Undelaying Mechanism of HA-Subtyping in the Level of PhysicChemical Characteristics of Protein. PloS one 9: e96984

Ebrahimie M, Esmaeili F, Cheraghi S, Houshmand F, Shabani L, Ebrahimie E (2014) Efficient and Simple Production of Insulin-Producing Cells from Embryonal Carcinoma Stem Cells Using Mouse Neonate Pancreas Extract, As a Natural Inducer. PloS one 9: e90885

El-Kordi A, Kästner A, Grube S, Klugmann M, Begemann M, Sperling S, Hammerschmidt K, Hammer C, Stepniak B, Patzig J (2013) A single gene defect causing claustrophobia. Translational psychiatry 3: e254 Eldridge AG, Loktev AV, Hansen DV, Verschuren EW, Reimann JD, Jackson PK (2006) The evi5 oncogene regulates cyclin accumulation by stabilizing the anaphase-promoting complex inhibitor emi1. Cell 124: 367-380

Fatemi SH, Pearce DA, Brooks Al, Sidwell RW (2005) Prenatal viral infection in mouse causes differential expression of genes in brains of mouse progeny: A potential animal model for schizophrenia and autism. Synapse 57: 91-99

Fox RJ, Dimmic MW (2006) A two-sample Bayesian t-test for microarray data. BMC Bioinformatics 7: 126 Frank M, Kemler R (2002) Protocadherins. Curr Opin Cell Biol 14: 557-562

Fruzangohar M, Ebrahimie E, Adelson DL (2014) Application of Global Transcriptome Data in Gene Ontology Classification and Construction of a Gene Ontology Interaction Network. bioRxiv

Fruzangohar M, Ebrahimie E, Ogunniyi AD, Mahdi LK, Paton JC, Adelson DL (2013) Comparative GO: A web application for comparative gene ontology and gene ontology-based gene selection in bacteria. PloS one 8: e58759

Gitler AD, Bevis BJ, Shorter J, Strathearn KE, Hamamichi S, Su L, Caldwell KA, Caldwell GA, Rochet J-C, McCaffery JM, Barlowe C, Lindquist S (2008) The Parkinson's disease protein $\alpha$-synuclein disrupts cellular Rab homeostasis. Proceedings of the National Academy of Sciences 105: 145-150

Hanger DP, Byers HL, Wray S, Leung KY, Saxton MJ, Seereeram A, Reynolds CH, Ward MA, Anderton BH (2007) Novel phosphorylation sites in tau from Alzheimer brain support a role for casein kinase 1 in disease pathogenesis. J Biol Chem 282: 23645-23654 
He L, Hannon GJ (2004) MicroRNAs: small RNAs with a big role in gene regulation. Nat Rev Genet 5: 522531

Hille B G protein-coupled mechanisms and nervous signaling. Neuron 9: 187-195

Hipfel R, Hanes J, Von Der Kammer H, Pohlner J (2003) Camp-regulated phosphoprotein for diagnostic and therapeutic use in neurodegenerative diseases. Google Patents

Hobert O (2008) Gene Regulation by Transcription Factors and MicroRNAs. Science 319: 1785-1786

Hoshikawa S, Ogata T, Fujiwara S, Nakamura K, Tanaka S (2008) A novel function of RING finger protein 10 in transcriptional regulation of the myelin-associated glycoprotein gene and myelin formation in Schwann cells. PLoS One 3: e3464

Hosseinpour B, Bakhtiarizadeh MR, Khosravi P, Ebrahimie E (2013) Predicting distinct organization of transcription factor binding sites on the promoter regions: a new genome-based approach to expand human embryonic stem cell regulatory network. Gene 531: 212-219

Hosseinpour B, Hajihoseini V, Kashfi R, Ebrahimie E, Hemmatzadeh F (2012) Protein Interaction Network of Arabidopsis thaliana Female Gametophyte Development Identifies Novel Proteins and Relations. PLoS One 7: e49931

Huang X, Fu Y, Charbeneau RA, Saunders TL, Taylor DK, Hankenson KD, Russell MW, D'Alecy LG, Neubig RR (2006) Pleiotropic phenotype of a genomic knock-in of an RGS-insensitive G184S Gnai2 allele. Mol Cell Biol 26: 6870-6879

Huang Y, Higginson DS, Hester L, Park MH, Snyder SH (2007) Neuronal growth and survival mediated by elF5A, a polyamine-modified translation initiation factor. Proc Natl Acad Sci U S A 104: 4194-4199

Inoue J, Misawa A, Tanaka Y, Ichinose S, Sugino Y, Hosoi H, Sugimoto T, Imoto I, Inazawa J (2009) Lysosomal-Associated Protein Multispanning Transmembrane <italic $>5</$ italic $>$ Gene (<italic $>$ LAPTM5</italic $>$ ) Is Associated with Spontaneous Regression of Neuroblastomas. PLoS One 4: e7099

Lawrence MS, Stojanov P, Polak P, Kryukov GV, Cibulskis K, Sivachenko A, Carter SL, Stewart C, Mermel $\mathrm{CH}$, Roberts SA (2013) Mutational heterogeneity in cancer and the search for new cancer-associated genes. Nature

Lee N, Wong CK, Chan PK, Lindegardh N, White NJ, Hayden FG, Wong EH, Wong KS, Cockram CS, Sung JJ, Hui DS (2010) Acute encephalopathy associated with influenza A infection in adults. Emerg Infect Dis 16: 139-142

Leon CA, Schumacher J, Kluck N, Herold C, Schulze TG, Propping P, Rietschel M, Cichon S, Nothen MM, Jamra RA (2011) Association study of the GRIA1 and CLINT1 (Epsin 4) genes in a German schizophrenia sample. Psychiatr Genet 21: 114

Lin JC, Hsu M, Tarn WY (2007) Cell stress modulates the function of splicing regulatory protein RBM4 in translation control. Proc Natl Acad Sci U S A 104: 2235-2240

Liu QY, Lei JX, Sikorska M, Liu R (2008a) A novel brain-enriched E3 ubiquitin ligase RNF182 is up regulated in the brains of Alzheimer's patients and targets ATP6VOC for degradation. Mol Neurodegener 3: 4

Liu Y, Gervasi C, Szaro BG (2008b) A crucial role for hnRNP K in axon development in Xenopus laevis. Development 135: 3125-3135

Lowe XR, Bhattacharya S, Marchetti F, Wyrobek AJ (2009) Early Brain Response to Low-Dose Radiation Exposure Involves Molecular Networks and Pathways Associated with Cognitive Functions, Advanced Aging and Alzheimer's Disease. Radiation Research 171: 53-65

Mahdi LK, Ebrahimie E, Adelson DL, Paton JC, Ogunniyi AD (2013) A transcription factor contributes to pathogenesis and virulence in Streptococcus pneumoniae. PloS one 8: e70862

Markowetz F, Spang R (2007) Inferring cellular networks-a review. BMC bioinformatics 8: S5

Marson A, Levine SS, Cole MF, Frampton GM, Brambrink T, Johnstone S, Guenther MG, Johnston WK, Wernig M, Newman J, Calabrese JM, Dennis LM, Volkert TL, Gupta S, Love J, Hannett N, Sharp PA, Bartel 
DP, Jaenisch R, Young RA (2008) Connecting microRNA Genes to the Core Transcriptional Regulatory Circuitry of Embryonic Stem Cells. Cell 134: 521-533

Maurizi CP (1985) Why was the 1918 influenza pandemic so lethal? The possible role of a neurovirulent neuraminidase. Medical Hypotheses 16: 1-5

McLaughlin HM, Sakaguchi R, Liu C, Igarashi T, Pehlivan D, Chu K, Iyer R, Cruz P, Cherukuri PF, Hansen NF, Mullikin JC, Biesecker LG, Wilson TE, Ionasescu V, Nicholson G, Searby C, Talbot K, Vance JM, Zuchner S, Szigeti K, Lupski JR, Hou YM, Green ED, Antonellis A (2010) Compound heterozygosity for loss-of-function lysyl-tRNA synthetase mutations in a patient with peripheral neuropathy. Am J Hum Genet 87: 560-566

Michibata H, Okuno T, Konishi N, Kyono K, Wakimoto K, Aoki K, Kondo Y, Takata K, Kitamura Y, Taniguchi T (2009) Human GPM6A is associated with differentiation and neuronal migration of neurons derived from human embryonic stem cells. Stem Cells Dev 18: 629-639

Miller CL, Llenos IC, Dulay JR, Weis S (2006) Upregulation of the initiating step of the kynurenine pathway in postmortem anterior cingulate cortex from individuals with schizophrenia and bipolar disorder. Brain Res 1073-1074: 25-37

Mills CE, Robins JM, Lipsitch M (2004) Transmissibility of 1918 pandemic influenza. Nature 432: 904-906 Moon IS, Lee HJ, Park IS (2012) Dendritic elF4E-binding protein 1 (elF4E-BP1) mRNA is upregulated by neuronal activation. J Korean Med Sci 27: 1241-1247

Mori I, Hossain MJ, Takeda K, Okamura H, Imai Y, Kohsaka S, Kimura Y (2001) Impaired Microglial Activation in the Brain of IL-18-Gene-Disrupted Mice after Neurovirulent Influenza A Virus Infection. Virology 287: 163-170

Nikitin A, Egorov S, Daraselia N, Mazo I (2003) Pathway studio - the analysis and navigation of molecular networks. Bioinformatics 19: 2155-2157

Niman HL (2007) Swine influenza A evolution via recombination - genetic drift reservoir. Nat. Precedings http://hdl. handle. net/10101/npre 1

Novarino G, El-Fishawy P, Kayserili H, Meguid NA, Scott EM, Schroth J, Silhavy JL, Kara M, Khalil RO, BenOmran T, Ercan-Sencicek AG, Hashish AF, Sanders SJ, Gupta AR, Hashem HS, Matern D, Gabriel S, Sweetman L, Rahimi Y, Harris RA, State MW, Gleeson JG (2012) Mutations in BCKD-kinase lead to a potentially treatable form of autism with epilepsy. Science 338: 394-397

Novichkova S, Egorov S, Daraselia N (2003) MedScan, a natural language processing engine for MEDLINE abstracts. Bioinformatics 19: 1699-1706

Obayashi T, Okamura Y, Ito S, Tadaka S, Motoike IN, Kinoshita K (2013) COXPRESdb: a database of comparative gene coexpression networks of eleven species for mammals. Nucleic acids research 41: D1014-D1020

Pan C, Wang G, Liao M, Zhang G-H, Jiang S (2009) High genetic and antigenic similarity between a swine H3N2 influenza A virus and a prior human influenza vaccine virus: A possible immune pressure-driven cross-species transmission. Biochemical and biophysical research communications 385: 402-407

Pfuhl T, Mamiani A, Durr M, Welter S, Stieber J, Ankara J, Liss M, Dobner T, Schmitt A, Falkai P, Kremmer E, Jung V, Barth S, Grasser FA (2008) The LARK/RBM4a protein is highly expressed in cerebellum as compared to cerebrum. Neurosci Lett 444: 11-15

Pohlenz J, Dumitrescu A, Zundel D, Martine U, Schonberger W, Koo E, Weiss RE, Cohen RN, Kimura S, Refetoff S (2002) Partial deficiency of thyroid transcription factor 1 produces predominantly neurological defects in humans and mice. J Clin Invest 109: 469-473

Ren Z, Wang Y, Liebenson D, Liggett T, Goswami R, Stefoski D, Balabanov R (2011) IRF-1 signaling in central nervous system glial cells regulates inflammatory demyelination. J Neuroimmunol 233: 147-159 Roberts T, Chernova O, Cowell JK (1998) NB4S, a member of the TBC1 domain family of genes, is truncated as a result of a constitutional $\mathrm{t}(1 ; 10)(\mathrm{p} 22 ; \mathrm{q} 21)$ chromosome translocation in a patient with stage 4S neuroblastoma. Hum Mol Genet 7: 1169-1178 
Rowe T, Leon AJ, Crevar CJ, Carter DM, Xu L, Ran L, Fang Y, Cameron CM, Cameron MJ, Banner D, Ng DC, Ran R, Weirback HK, Wiley CA, Kelvin DJ, Ross TM (2010) Modeling host responses in ferrets during A/California/07/2009 influenza infection. Virology 401: 257-265

Ruan J, Dean AK, Zhang W (2010) A general co-expression network-based approach to gene expression analysis: comparison and applications. BMC systems biology 4: 8

Safran M, Solomon I, Shmueli O, Lapidot M, Shen-Orr S, Adato A, Ben-Dor U, Esterman N, Rosen N, Peter I (2002) GeneCards ${ }^{\mathrm{TM}}$ 2002: towards a complete, object-oriented, human gene compendium. Bioinformatics 18: 1542-1543

Sanchez-Palencia A, Gomez-Morales M, Gomez-Capilla JA, Pedraza V, Boyero L, Rosell R, Farez-Vidal ME (2011) Gene expression profiling reveals novel biomarkers in nonsmall cell lung cancer. Int J Cancer 129: 355-364

Shalgi R, Lieber D, Oren M, Pilpel Y (2007) Global and Local Architecture of the Mammalian microRNATranscription Factor Regulatory Network. PLoS Comput Biol 3: e131

Shannon P, Markiel A, Ozier O, Baliga NS, Wang JT, Ramage D, Amin N, Schwikowski B, Ideker T (2003) Cytoscape: a software environment for integrated models of biomolecular interaction networks. Genome research 13: 2498-2504

Stuart JM, Segal E, Koller D, Kim SK (2003) A Gene-Coexpression Network for Global Discovery of Conserved Genetic Modules. Science 302: 249-255

Studahl M (2003) Influenza virus and CNS manifestations. J Clin Virol 28: 225-232

Subramanian A, Tamayo P, Mootha VK, Mukherjee S, Ebert BL, Gillette MA, Paulovich A, Pomeroy SL, Golub TR, Lander ES, Mesirov JP (2005) Gene set enrichment analysis: A knowledge-based approach for interpreting genome-wide expression profiles. Proceedings of the National Academy of Sciences of the United States of America 102: 15545-15550

Sussel L, Marin O, Kimura S, Rubenstein JL (1999) Loss of Nkx2.1 homeobox gene function results in a ventral to dorsal molecular respecification within the basal telencephalon: evidence for a transformation of the pallidum into the striatum. Development 126: 3359-3370

Tan K, Prerna A, Leo YS (2010) Surveillance of H1N1-related neurological complications. Lancet Neurol 9: 142-143

Terabayashi T, Itoh TJ, Yamaguchi H, Yoshimura Y, Funato Y, Ohno S, Miki H (2007) Polarity-regulating kinase partitioning-defective $1 /$ microtubule affinity-regulating kinase 2 negatively regulates development of dendrites on hippocampal neurons. J Neurosci 27: 13098-13107

Toovey S (2008) Influenza-associated central nervous system dysfunction: A literature review. Travel medicine and infectious disease 6: 114-124

Urny J, Hermans-Borgmeyer I, Gercken G, Schaller HC (2003) Expression of the presenilin-like signal peptide peptidase (SPP) in mouse adult brain and during development. Gene Expr Patterns 3: 685-691

Valleron AJ, Cori A, Valtat S, Meurisse S, Carrat F, Boelle PY (2010) Transmissibility and geographic spread of the 1889 influenza pandemic. Proc Natl Acad Sci U S A 107: 8778-8781

Wong CKS, Zhu H, Li OTW, Leung YHC, Chan MCW, Guan Y, Peiris JSM, Poon LLM (2013) Molecular Detection of Human H7N9 Influenza A Virus Causing Outbreaks in China. Clinical Chemistry 59: 10621067

Wu X, Jiang R, Zhang MQ, Li S (2008) Network-based global inference of human disease genes. Molecular systems biology 4: 189

Zhang B, Horvath S (2005) A general framework for weighted gene co-expression network analysis. Statistical applications in genetics and molecular biology 4: 1128

Zhang $\mathrm{H}$, Constantine R, Vorobiev S, Chen Y, Seetharaman J, Huang YJ, Xiao R, Montelione GT, Gerstner CD, Davis MW, Inana G, Whitby FG, Jorgensen EM, Hill CP, Tong L, Baehr W (2011) UNC119 is required for $G$ protein trafficking in sensory neurons. Nat Neurosci 14: 874-880 


\section{Tables}

Table 1. The host genes which solely modulated (upregulated/downregulated) in response to pandemic influenza virus compared to seasonal/non-pandemic influenza)

\begin{tabular}{|c|c|c|c|c|}
\hline $\begin{array}{c}\text { Gene } \\
\text { symbol }\end{array}$ & Gene title & Relation to Nervous system & $\begin{array}{l}\text { Symmetric } \\
\text { fold } \\
\text { change }\end{array}$ & $\begin{array}{l}\text { Host } \\
\text { response to } \\
\text { pandemic } \\
\text { influenza }\end{array}$ \\
\hline GPМбА & Glycoprotein M6A & $\begin{array}{l}\text { Involved in neuronal differentiation, plays a role in } \\
\text { neuronal plasticity, involved in neurite and filopodia } \\
\text { outgrowth, filopodia motility and probably synapse } \\
\text { formation (Michibata et al. 2009) }\end{array}$ & -5.22 & Down \\
\hline EVI5 & $\begin{array}{l}\text { Ecotropic viral integration } \\
\text { site } 5\end{array}$ & $\begin{array}{l}\text { Expressed in a wide range of tissues including brain } \\
\text { and adrenal (http://www.uniprot.org/uniprot/O60447) }\end{array}$ & -2.11 & Down \\
\hline РCDHAC2 & $\begin{array}{l}\text { Protocadherin alpha } \\
\text { subfamily C2 }\end{array}$ & $\begin{array}{l}\text { involved in the establishment and maintenance of } \\
\text { specific neuronal connections in the brain (Frank and } \\
\text { Kemler 2002) }\end{array}$ & -2.2 & Down \\
\hline Arpp-21 & $\begin{array}{c}\text { CAMP regulated } \\
\text { phosphoprotein }, 21 \mathrm{KD}\end{array}$ & $\begin{array}{l}\text { Act as a competitive inhibitor of calmodulin- } \\
\text { dependent enzymes such as calcineurin in neurons } \\
\text { (http://www.uniprot.org/uniprot/Q9UBL0) }\end{array}$ & -2.09 & Down \\
\hline
\end{tabular}

*Negative sign shows downregulation. 
Table 2. Statistically significant subnetworks generated by specifically downregulated genes by pandemic influenza compared to non-pandemic influenza

\begin{tabular}{|c|c|c|c|c|c|c|c|c|}
\hline Name & $\begin{array}{l}\text { Total \# of } \\
\text { Neighbors }\end{array}$ & $\begin{array}{c}\text { Gene Set } \\
\text { Seed }\end{array}$ & Overlap & $\begin{array}{l}\text { Percent } \\
\text { Overlap }\end{array}$ & $\begin{array}{l}\text { Overlapping } \\
\text { Entities }\end{array}$ & $\begin{array}{c}\text { p- } \\
\text { value }\end{array}$ & $\begin{array}{c}\text { Jaccard } \\
\text { similarity }\end{array}$ & Hit type \\
\hline $\begin{array}{l}\text { Neighbors of } \\
\text { Mir367 }\end{array}$ & 16 & Mir367 & 2 & 11 & GPM6A;EVI5 & 0.00 & 0.11 & Regulation \\
\hline $\begin{array}{l}\text { Neighbors of } \\
\text { MIR15B }\end{array}$ & 170 & MIR15B & 2 & 1 & PCDHAC2;ARPP21 & 0.00 & 0.01 & Regulation \\
\hline $\begin{array}{l}\text { Neighbors of } \\
\text { EVI5 }\end{array}$ & 3 & EVI5 & 1 & 25 & EVI5 & 0.00 & 0.14 & Regulation \\
\hline $\begin{array}{l}\text { Neighbors of } \\
\text { ARPP21 }\end{array}$ & 3 & ARPP21 & 1 & 25 & ARPP21 & 0.00 & 0.14 & Regulation \\
\hline $\begin{array}{l}\text { Neighbors of } \\
\text { GPM6A }\end{array}$ & 6 & GPM6A & 1 & 14 & GPM6A & 0.00 & 0.10 & Regulation \\
\hline $\begin{array}{l}\text { Neighbors of } \\
\text { Mir325 }\end{array}$ & 6 & Mir325 & 1 & 14 & ARPP21 & 0.00 & 0.10 & Regulation \\
\hline $\begin{array}{l}\text { Neighbors of } \\
\text { MIR128-1 }\end{array}$ & 414 & MIR128-1 & 2 & 0 & EVI5;ARPP21 & 0.00 & 0.00 & Regulation \\
\hline $\begin{array}{l}\text { Neighbors of } \\
\text { MIR128-2 }\end{array}$ & 18 & MIR128-2 & 1 & 5 & ARPP21 & 0.00 & 0.05 & Regulation \\
\hline $\begin{array}{l}\text { Neighbors of } \\
\text { ZDHHC17 }\end{array}$ & 21 & ZDHHC17 & 1 & 4 & GPM6A & 0.00 & 0.04 & Regulation \\
\hline $\begin{array}{l}\text { Neighbors of } \\
\text { PPP1R1B }\end{array}$ & 44 & PPP1R1B & 1 & 2 & ARPP21 & 0.01 & 0.02 & Regulation \\
\hline $\begin{array}{l}\text { Neighbors of } \\
\text { Mir182 }\end{array}$ & 54 & Mir182 & 1 & 1 & EVI5 & 0.01 & 0.02 & Regulation \\
\hline $\begin{array}{l}\text { Neighbors of } \\
\text { Mir182 }\end{array}$ & 62 & Mir182 & 1 & 1 & EVI5 & 0.01 & 0.02 & Regulation \\
\hline $\begin{array}{l}\text { Neighbors of } \\
\text { MIR217 }\end{array}$ & 87 & MIR217 & 1 & 1 & GPM6A & 0.02 & 0.01 & Regulation \\
\hline $\begin{array}{l}\text { Neighbors of } \\
\text { MIR185 }\end{array}$ & 91 & MIR185 & 1 & 1 & PCDHAC2 & 0.02 & 0.01 & Regulation \\
\hline $\begin{array}{l}\text { Neighbors of } \\
\text { MIR133B }\end{array}$ & 94 & MIR133B & 1 & 1 & GPM6A & 0.02 & 0.01 & Regulation \\
\hline $\begin{array}{l}\text { Neighbors of } \\
\text { MIR367 }\end{array}$ & 108 & MIR367 & 1 & 0 & GPM6A & 0.02 & 0.01 & Regulation \\
\hline $\begin{array}{l}\text { Neighbors of } \\
\text { CARM1 }\end{array}$ & 109 & CARM1 & 1 & 0 & ARPP21 & 0.02 & 0.01 & Regulation \\
\hline $\begin{array}{l}\text { Neighbors of } \\
\text { DRD1 }\end{array}$ & 180 & DRD1 & 1 & 0 & ARPP21 & 0.03 & 0.01 & Regulation \\
\hline $\begin{array}{l}\text { Neighbors of } \\
\text { MIR221 }\end{array}$ & 218 & MIR221 & 1 & 0 & PCDHAC2 & 0.04 & 0.00 & Regulation \\
\hline $\begin{array}{l}\text { Neighbors of } \\
\text { DRD2 }\end{array}$ & 223 & DRD2 & 1 & 0 & ARPP21 & 0.04 & 0.00 & Regulation \\
\hline $\begin{array}{l}\text { Neighbors of } \\
\text { PLK1 }\end{array}$ & 240 & PLK1 & 1 & 0 & EVI5 & 0.05 & 0.00 & Regulation \\
\hline Neighbors of & 246 & NGF family & 1 & 0 & ARPP21 & 0.05 & 0.00 & Regulation \\
\hline
\end{tabular}




\begin{tabular}{lllllllll}
\hline $\begin{array}{l}\text { NGF family } \\
\text { Neighbors of } \\
\text { MIR15A }\end{array}$ & 262 & MIR15A & 1 & 0 & ARPP21 & 0.05 & 0.00 & Regulation \\
\hline
\end{tabular}




\section{Figure Caption}

Figure 1. Analyzing workflow of determining differential evolution of pandemic influenza (A/California/07/2009), compared to seasonal influenza (A/Brisbane/59/2007), in altering mammalian host immune response.

Figure 2. Significant microRNA based subnetworks generated by the genes. Network for up and downregulated genes involved in neural disaster host neuronal related genes specific to pandemic influenza infection.

Figure 3. Network for up and downregulated genes involved in neural disorder specific to pandemic influenza infection. The orange box shows that the gene is upregulated. The green box shows that the gene is downregulated. The blue box represents the gene which is added by network analysis. Different lines (in the term of color and type) show different types of interactions which is schematically explained in Figure.

Figure 4. Interactions between nodes of host up/downregulated genes by pandemic influenza. A: Crosstalk between FN1, IRF, NKX2-1, NR5A1 B: Expression target analysis between FN1, IRF1, $N K X 2-1$, and NR5A1. The orange box shows that the gene is upregulated. The green box shows that the gene is downregulated. The blue box represents the gene which is added by network analysis. Different lines (in the term of color and type) show different types of interactions which is schematically explained in Figure.

Figure 5. Crosstalk between genes involved in neuronal disorders and cytokine storm.

Figure 6. Gene Ontology (GO) regulatory network of host genes which merely downregulated by pandemic influenza compared to seasonal (non-pandemic) influenza. Size of circles is the number of genes and their splicing variants in each Gene Ontology group.

Figure 7. Gene Ontology (GO) distribution of host neuronal related genes which solely downregulate by pandemic influenza verses GO distribution of genome in terms of (A) Biological Process, (B) Molecular Function, and (C) Cellular Component. 


\section{Supplementary caption}

Supplementary 1. Subnetworks enriched with 27 gene which solely modulate (up/downregulate) in response to pandemic influenza virus compared to seasonal (nonpandemic) influenza.

Supplementary2. Relations of network for up and downregulated genes involved in neural disorder specific to pandemic influenza infection.

Supplementary 3. Relations of interactions between nodes (Crosstalk between FN1, IRF, NKX2-1, NR5A1) of host up/downregulated genes by pandemic influenza.

Supplementary 4. Relations of interactions between nodes (Expression target between FN1, IRF1, NKX2-1, NR5A1) of host up/downregulated genes by pandemic influenza.

Supplementary 5. Relations of crosstalk between genes involved in neuronal disorders and cytokine storm. 


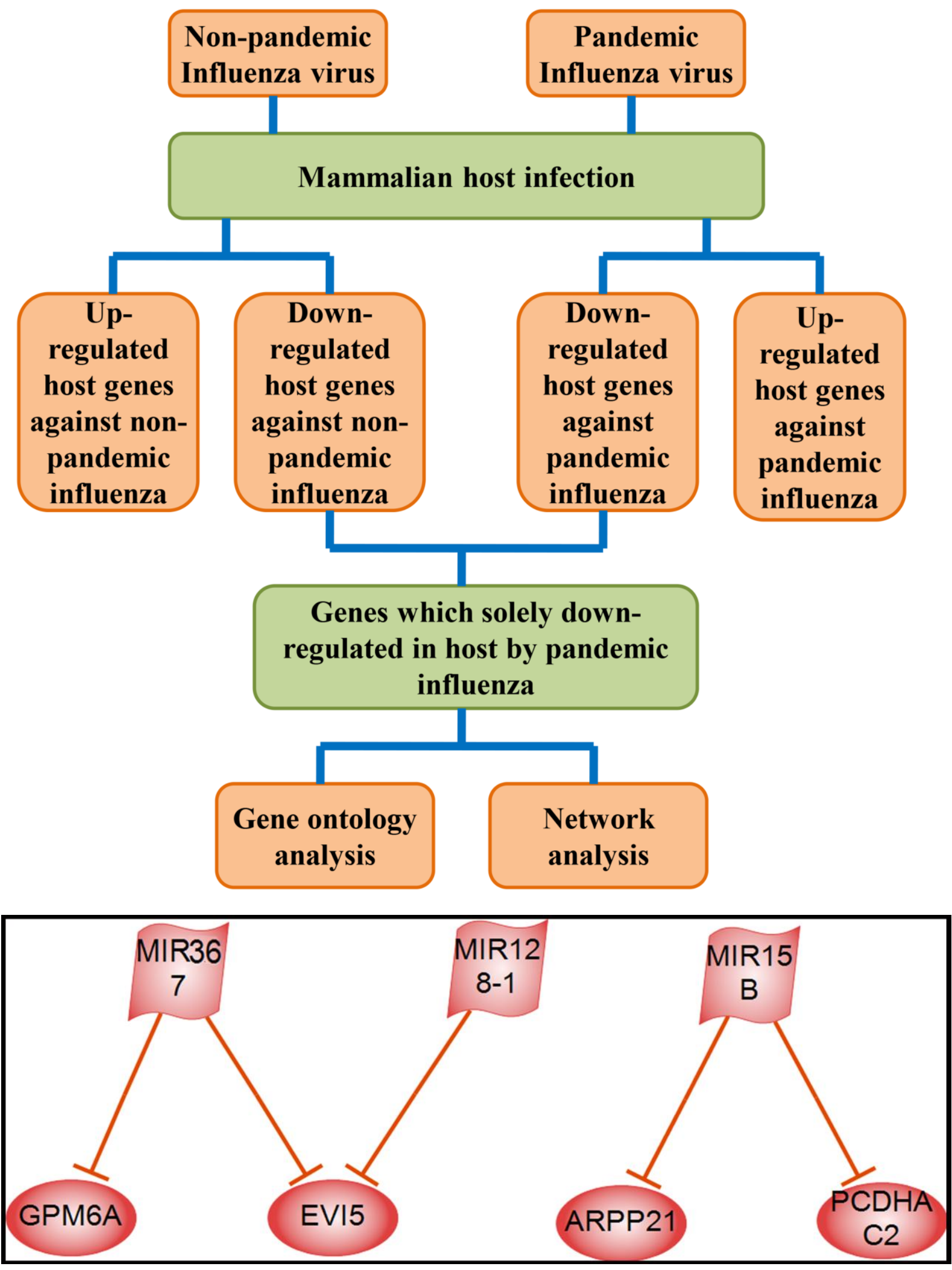




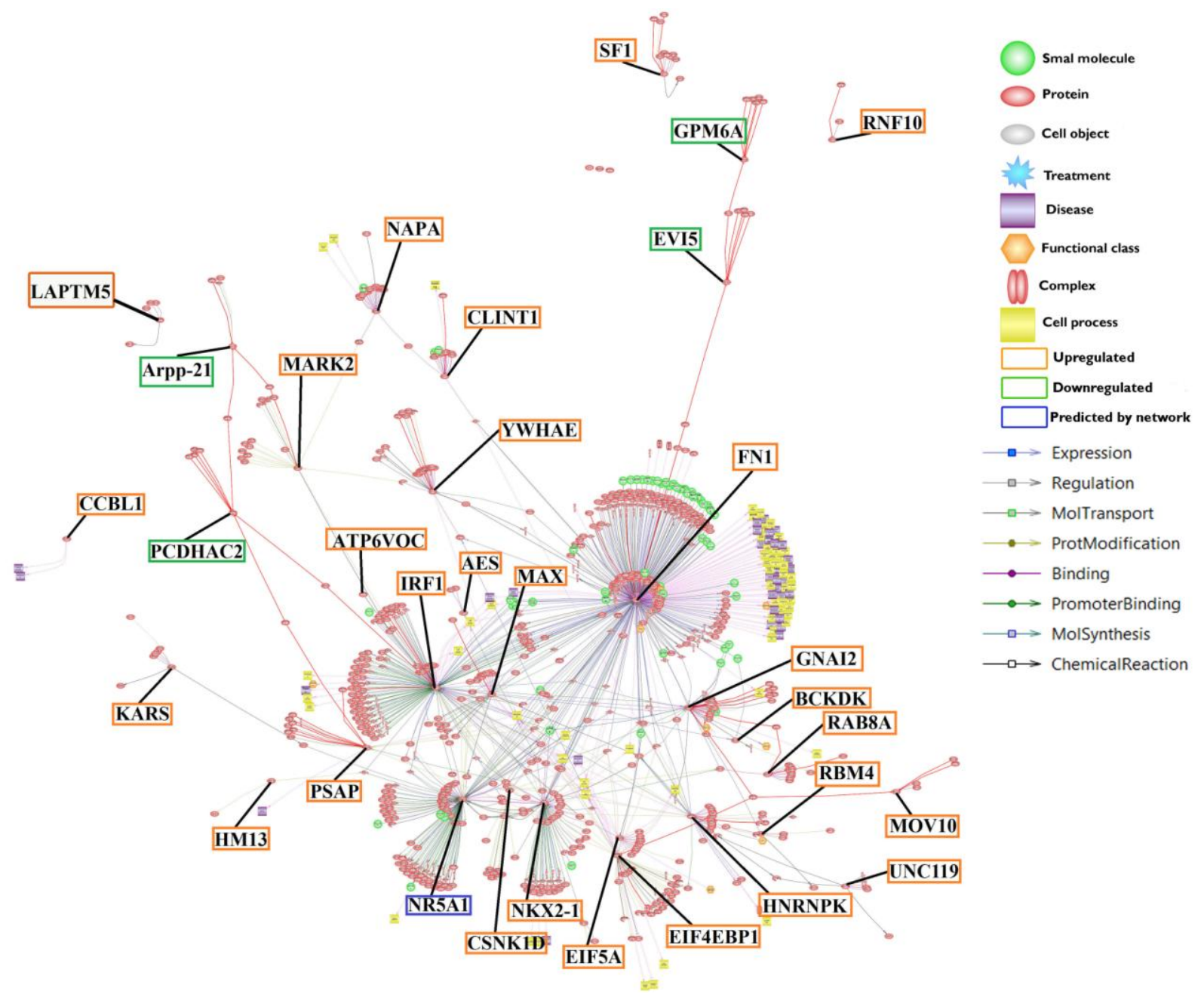

A

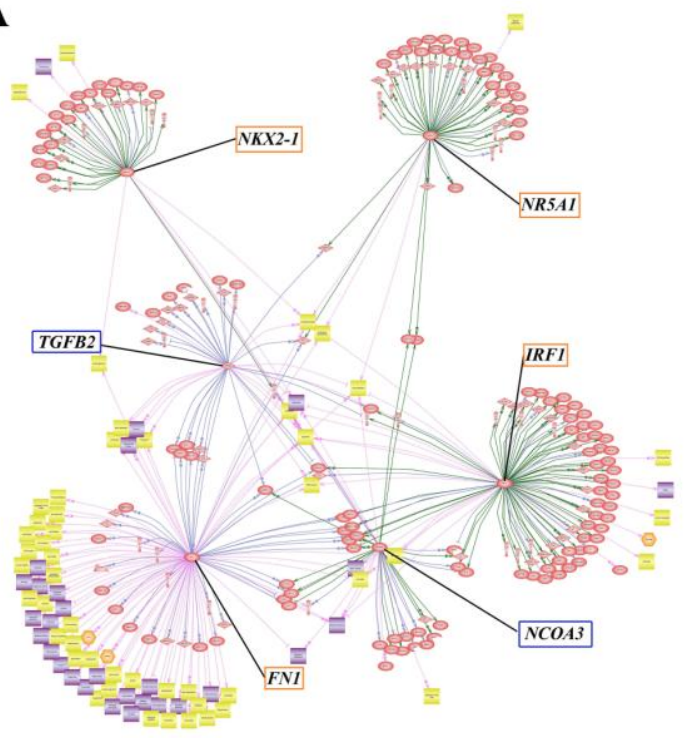

B

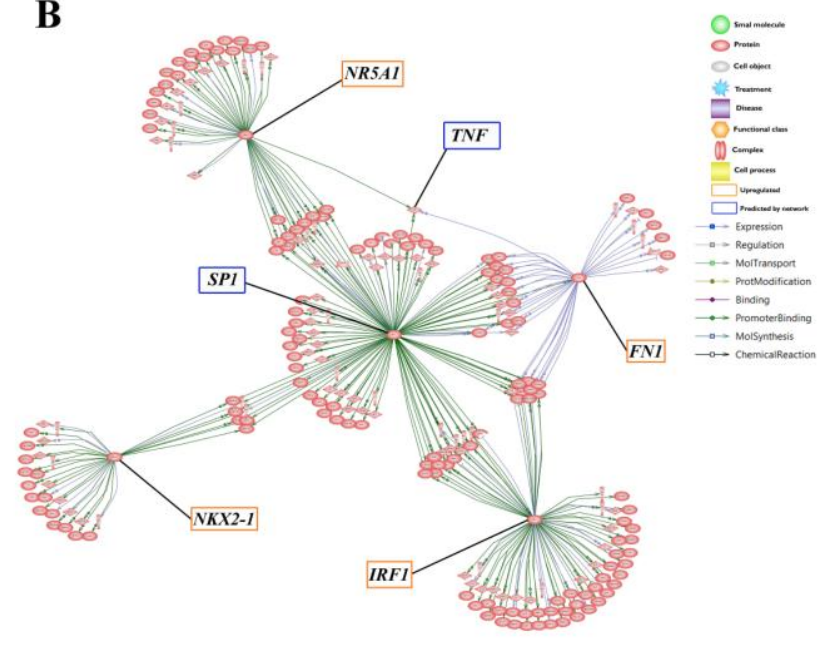




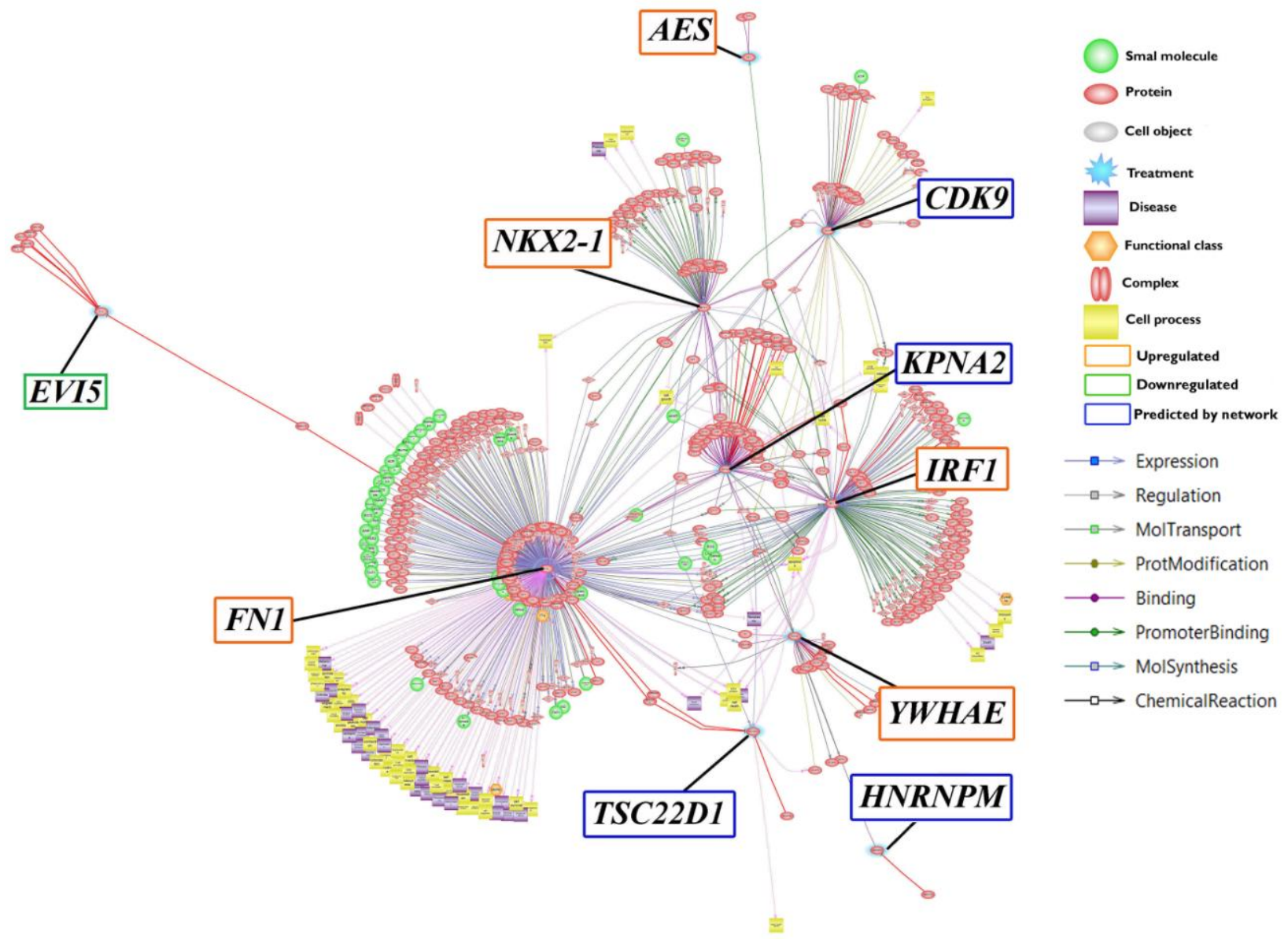




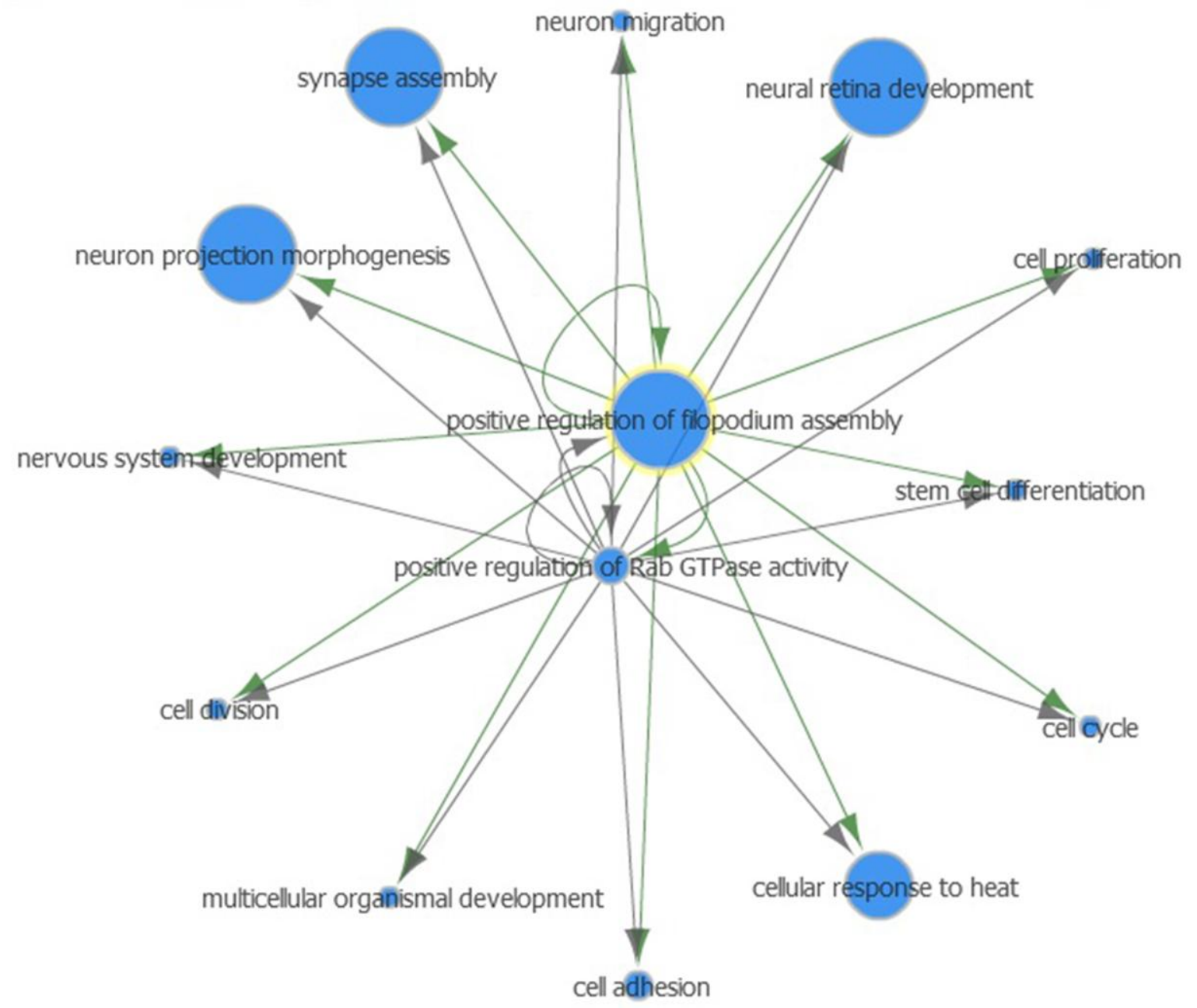



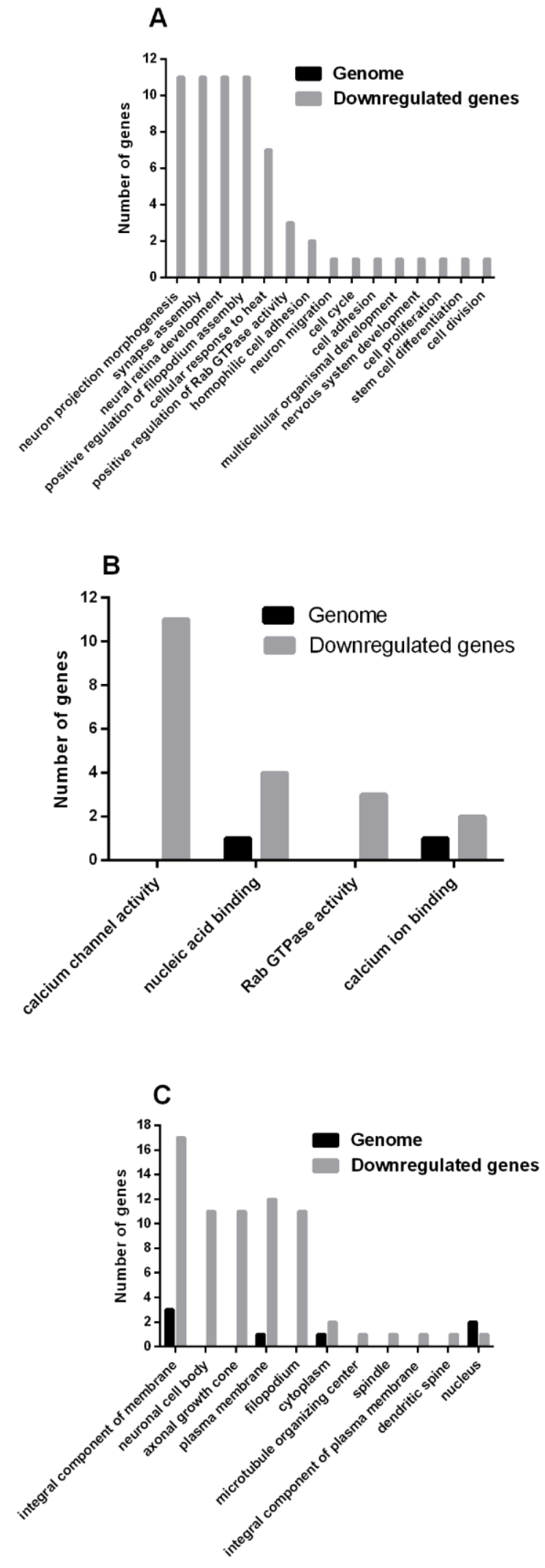



\section{University Library}

\section{- M M I E E R VA A gateway to Melbourne's research publications}

Minerva Access is the Institutional Repository of The University of Melbourne

Author/s:

Ebrahimie, E;Nurollah, Z;Ebrahimi, M;Hemmatzadeh, F;Ignjatovic, J

Title:

Unique ability of pandemic influenza to downregulate the genes involved in neuronal disorders

Date:

2015-09-01

Citation:

Ebrahimie, E., Nurollah, Z., Ebrahimi, M., Hemmatzadeh, F. \& Ignjatovic, J. (2015). Unique ability of pandemic influenza to downregulate the genes involved in neuronal disorders. MOLECULAR BIOLOGY REPORTS, 42 (9), pp.1377-1390. https://doi.org/10.1007/ s11033-015-3916-4.

Persistent Link:

http://hdl.handle.net/11343/282562 